\title{
3 次元弾性問題の一数值解法とその応用 \\ A METHOD OF NUMERICAL ANALYSIS OF THREE-DIMENSIONAL ELASTIC PROBLEMS WITH ITS APPLICATIONS
}

\author{
岡 村 宏 一**島 田 功** \\ By Hirokazu Okamura and Isao Shimada
}

\section{1. まえがき}

3 次元弾性, 特に非軸対称の問題に関して, 高精度, かつ取扱いの便利な一般的解法を見出すことは, 従来, 2 次元問題として略近的に処理されていた諸問題や，局 所的な問題に関して，忠実な評価を与える資料を提示で きることを意味する。しかしながら，この領域の問題は， 久しく弾性力学の分野における難関の 1 つとされ, 目下 のところ研究例も数少ない。本文は, この問題に関する 1 つの解法と, 若干の応用例について述べるものであ る注1)。

3 次元弾性問題に関する既往の研究例として, まず, 軸対称問題については，Z. Sternberg，および I.N. Sneddon一派の人々によってかなり研究されたが3)，そ れすら解析は繁雑である。一方, 非軸対称問題に関して は, 級数解法に基つくく K.T. Iyengar ${ }^{4), 5)}$ らの解析, 部 分的に差分法を用いる色部 ${ }^{6}$ らの解法も見られるが，上 り一般性のある解法として，3 次元要素を用いる有限要 素法によるアプローチㄱ 10) が研究されている。しかし ながら, 有限要素法による場合も， 3 次元非軸対称の問 題となると，マトリックスに扔けるバンドの幅が広くな り，この方法の特色の 1 つがかなり失われる感がある。 また，この方法を用いる場合，しばしば，要素分割，そ の他について適当な検証の資料が必要であるが，非軸状 態, 特に, 局所的な精度について検討を行なうことので きる厳密な解析資料は数少なく, 設計者にとって, 計算 容量と望をしい精度の間にある最適な条件を見出すため の情報が，目下のところ乏しいように思われる。また， この種の問題に対する実験（光弾性実験など）の結果は かなりばらつくことが多い。このような観点からすれば，

* 正会員 大阪工業大学助教授土木工学教室

** 正会員 大阪設計コンサルタンッ (株) 研究室

注 1) 本文は, 土木学会の講演概要 1)，2）を骨子とし，応 用ならびに照査に関するデータを加えて構成したもの である。
有限要素法のみならず, この種の問題に関し, 取扱いの 便利な, かつ精度の高い一般的な解法が多面的に研究さ れる必要がある。

さて, 前述の解法と系統を異にするものに, いわゆる Integral method ${ }^{11}$ がある。この種の方法の実際問題へ の適用, すなわち, 弾性体の内部に調整力を与え, $\sin$ gularity の問題を回避しつつ, 任意の境界を作り出す方

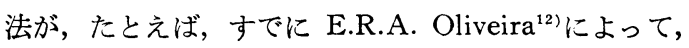
2 次元問題の解析に試みられ, 穴あきシャイベの問題に 関して, 精度の確認とともにすぐれた成果を提供してお り,また, 動的な問題への発展 ${ }^{13)}$ 見受けられる。な お，筆者は，曲げ，および面内力の両作用を受ける斜板 を含む構造物の解析に，このような考えを拉張して用い た ${ }^{14), 15)}$ 。

ところで, この種の解法は, 原理的に 3 次元問題に拡 張することが可能である。しかし， 3 次元，特に非軸対 称の実際的な問題に適用するには, Integral method 特 有の利点もあると同時に, 個々の問題についての精度, あるいは適用範囲の拡大に関して, 検討すべき多くの問 題があるように思える。

元来, この方法によれば, 弾性体の内点では field equation を満足する厳密な連続解が与えられており, ただ, 境界面のみに必要最小限の点を設けて解析するこ とになり, 差分法, あるいは有限要素法のように 3 次元 体の内部に解析上の点を配置する必要はない。境界の精 度が良好であれば十分な精度の解が期待できる。しかし， 境界調整を行ならための解法上の操作と精度との関連に ついて, 今後, 各種の問題に対し検証資料が積み上げら れる必要がある。

ところで, この方法では, 上記のように, 未知量は境 界上の点のみに対応するが, 一方, 原則としてマトリッ クスに 0 要素がない（もっとも, 前述のように, 有限要 素法でも 3 次元問題となるとバンド幅が広くなり,この 利点はかなり失われる)。ただ, 3 次元体の内部に与えら れる調整力の影響は, 離れた個所ではしばしば急激に減 
少するので，問題によっては Saint-Venant の原理を有 効に生かして解析を簡易化し, 計算容量を縮小できる方 法が考えられるが，この方面の研究も必要である。

以下, 解法, ならびに応用例として, 若干の 3 次元非 軸対称の問題について，異なった性格を持つ境界調整の 精度, 変形, 応力の分布などについて述べる。

\section{2. 解 法}

\section{（1）基 本 解}

本解法の基本的な性格は，半無限弾性体から，任意の 荷重状態, 形状, 境界条件を持つ， 3 次元弾性体を分離 することにある。当然, 任意の 3 次元体を分離すること ができるのと同様に，任意の穴を切り取ることもできる。

解法上，このような操作を行なうために，半無限体内 に，ナイフのような鋭い作用を持つ分布力が与えられて かくらんを起こす。ところで，このような力の作用位置 では，ある種の応力成分は singularity を持つ，したが って，そこでは望ましい条件を作り出すことはできな い。そこで，半無限体内に設定された任意のいくつかの 面（以下，これらを調整面と呼ぶ）に，これらの力の分 布を与え，真の境界面の条件は，それよりいくぶん離れ た位置において満足させる方法を用いる。すなわち，こ れらの分布力は調整力としての役割を果たすことにな る。

次に, 真の境界条件は, 選点法によって満足させられ る。また，境界面に対応する調整面を，比較的小さな長 方形面の結合したものとして構成することにより，3次 元体の形状や，境界条件として，原理的に任意なものを 採ることができる。

このような境界調整の方法は, 前述のように Oliveira $^{12)}$ が 2 次元問題の解析に用いているが，本解法 はこれを 3 次元問題に抬張したものである。

さて，3 次元弾性問題の一般的な見地からは, 弾性体 内にかくらんを起こす力を与える基本的な解は無限体内 に集中荷重を作用させる Lord Kelvin の解である。し かし， 3 次元弾性問題として扱われる実際問題は多岐に わたり，そのなかで，荷重を受ける平らな表面を持つ弾 性体の問題は実例の多いものである。本解法では，この 種の問題に対する実用上の適応性を考慮し, 弾性体内に かくらんを起こす力を与える解として, Kelvin 解より 鏡像の原理を用いて導かれた, 図一1に示すような, 半 無限弾性体内の任意点に垂直, ならびに水平方向の集中 カがそれぞれ作用する Mindlin 第 1, 第 2 問題の解 ${ }^{16)}$ を用いる。この際， $D=0$ とすれば表面力に対する Boussinesq, Cerruti らの解が得られ, これらの積分は,

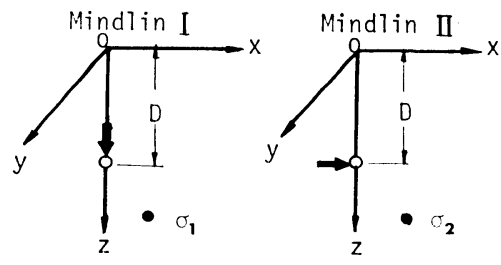

図-1

表面荷重に対する特解として利用される。また，Dの值 を大きく採れば，Mindlin 解は，Kelvin 解と類似の性 格を持つ。

次に，半無限体内にナイフのような作用をおよぼす分 布力の要素（調整面を構成する比較的小さい長方形面上 に分布する力）を，図一2 に見るように，前述の解をそ

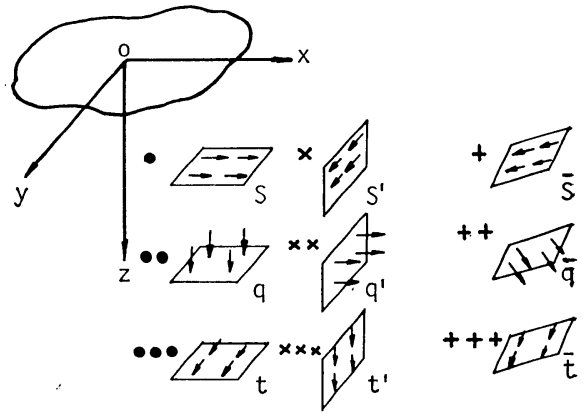

$\begin{array}{ll}- & s \times \int_{A} \sigma_{2} d A \\ \bullet & q \times \int_{A} \sigma_{1} d A \\ \bullet & t \times \int_{A} \sigma_{2} d A \\ + & \bar{s} \times \int_{\bar{A}_{1}} \sigma_{2} d \bar{A} \\ ++ & \bar{q} \times \int_{\bar{A}} F\left(\sigma_{1}, \sigma_{2}\right) d \bar{A} \\ +++ & \bar{t} \times \int_{\bar{A}} F\left(\sigma_{1}, \sigma_{2}\right) d \bar{A}\end{array}$

$\times \quad s^{\prime} \times \int_{A^{\prime}} \sigma_{2} d A^{\prime}$

$\times x \quad \dot{q} \times \rho_{x} \sigma_{5} d A^{\prime}$

$x \times x \quad \dot{t} \times \int_{A} \sigma_{1} d A^{\prime}$

れぞれ, 垂直, 水平, 斜め方向の長方形面に積分した形 で与える(以下，これらを基本解と呼ぶ)。それぞれの面 の法線，および接線方向に作用する各方向の分布力の強 さを，図のように， $s, q, t, \cdots \cdots$ で表わし，これらによ る弹性体内の任意点の応力成分 $(\sigma)$ を 図一2の下にある ように記述する。各積分值は次のような意味を持つ。た とえば,

$\int_{A}{ }^{\sigma_{1}} d A$ 単位荷重に対する Mindlin 第 1 問題の応 力成分の長方形水平面 $(A)$ での積分

$\int_{A^{\prime}} \sigma_{1} d A^{\prime}$ 単位荷重に対する Mindlin 第 1 問題の応 力成分の長方形垂直面 $\left(A^{\prime}\right)$ での積分

$\int_{A} \sigma_{2} d A, \int_{A^{\prime}} \sigma_{2} d A^{\prime}$ 同様に,単位荷重に対する $\mathrm{Min}$ dlin 第 2 問題の応力成分の長方 形水平，ならびに垂直面 ( $A$ ， $\left.A^{\prime}\right)$ での積分 
$\int_{\bar{A}} F\left(\sigma_{1}, \sigma_{2}\right) d \bar{A}$ 互いに直角なコンポーネントに対 する Mindlin 第 1 問題, 第 2 問 題の応力成分の長方形斜面 $(\bar{A})$ での積分の重ね合わせ

さらに, 特解として用いる, 半無限体の表面に作用する 垂直, および水平方向の分布力 (強さ $: q_{0}, s_{0}$ ) による忘 力成分, $q_{0} \times \int_{A}\left(\sigma_{1}\right)_{D=0} d A, s_{0} \times \int_{A}\left(\sigma_{2}\right)_{D=0} d A \quad$ が与え られる。ここで，それぞれの積分值は，前述の Boussinesq, および Cerruti の解に対応寸るものである。

以上は，応力成分に関するものであるが, 同様に, 変 位成分（ð）についても, 基本解, 寸なわち, $\int_{A} \delta_{1} d A$ $\int_{A^{\prime}} \delta_{1} d A^{\prime}, \cdots \cdots$ などが与えられる。

ところで, 従来, これら Mindlin 解の 2 重積分はむ ずかしいとされていたが，本解法に用いるものは積分可 能である。しかむ，これら基本解はすべて代数関数で与 えられ，解析上の取扱いは容易である。ここで，各種の 応力成分, および変位成分を与えるこれらの基本解を列 挙することは, 紙数の都合もあり, また, 本文の主旨で もないので割愛する。ただ，本文の末尾の付録に，精度 関するデータに関連して,その一部を提示してある。

さて, 調整面に作用させる調整力の分布を, 前述のよ うに, 比較的小さい有限領域で積分されたものの接合と れて与えるかわりに，1つの方法として，調整力の分布 を，適当な間隔を持たせた集中力の分布で与える方法を 用いても, singularity の問題を避け得る限り, 境界の 調整は可能である。しかしながら, Integral method 本 来の性格から言えば, 調整力の密度分布を, 適当な積分 によって与える方が解の精度は良好である。

たとえば，付録の図一24（a)，(b)，(c) は，半無限弾 性体内に設定された正方形水平面に等分布して作用する 垂直，および水平力による $Z$ 軸上注2）の応力，ならびに 変位成分の分布に関して, Mindlin 解の積分によって求 めた結果と, 水平面を $n \times n(n=2,4,10)$ 分割した集中 力の和として数值積分により求めた結果の比較を示した ものである。図より明らかなように, 後者による場合は, 分割の程度によって, 作用面の近くにおける解に乱れを 生じている。一方, 後の例題で述べるように, 境界調整 の精度を左右するものの 1 つに, 境界面と調整面の距離 がある。若干の解析を行なった経験では，これを大きく しすぎると満足すべき調整が得られないことがあり，か なり接近させた方が，よい結果を得る場合もある。調整

注 2）付録の記述にもあるように, 長方形水平面に作用する 分布力による応力および变位成分は, 長方形面の 1 つ の隅点を通る線上の点に対して与えられるが，重秝合 わせによって, 任意の長方形, および任意点に対する それらが求まる。
力の分布を集中力の和として与える場合は，この近傍で， 解の乱れを持つことになり，したがって，精度上，十分 な検討が必要である。

\section{（2）境界調整の方法}

さて, 図一-3によって, 半無限体から, 所要の 3 次元
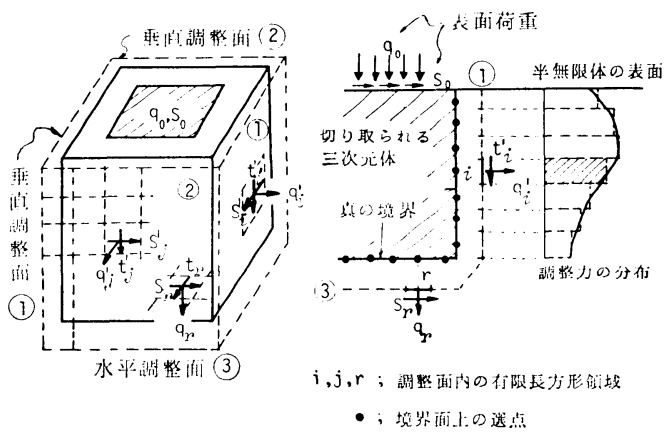

图-3

体を分離する操作を説明する。ここでは，まず，表面荷 重を受ける直方体の問題の扱いが示される。

図のように, 半無限体の表面に荷重を与え, 求める直 方体の外側を囲んで，垂直，および水平調整面 (1), (2), (3)を設定し，これらの調整面のそれぞれを，有限長方形 領域 $(i, j, r$ なぞ)によって分割する。さらに, 図一2 に示した方法で，これらの長方形領域のそれぞれにおい て等分布する調整力 $\left(q_{i}{ }^{\prime}, s_{i}{ }^{\prime}, t_{i}{ }^{\prime}\right.$ など) を与え, それら の作用によって, 真の境界面の境界条件を調整する。す なわち, 調整力は未知量である。また, 有限領域の分割, ならびに調整面と境界面の間の距離は境界条件の精度に 対応して定める。

いま，応力成分に対する境界条件の例として，境界面 （側面）上の選点 $m$ は自由，または一定の外力を受ける 条件を持つものとすれば，この点における垂直応力，お よび 2 方向のせん断応力に対し, 境界条件は次のように 書かれる。

$$
\begin{aligned}
\sigma_{m} & =\sum_{i}\left(s_{i}{ }^{\prime} \times \int_{A_{i^{\prime}}} \sigma_{2} d A^{\prime}+q_{i}{ }^{\prime} \times \int_{A_{i^{\prime}}} \sigma_{2} d A^{\prime}+t_{i}{ }^{\prime}\right. \\
& \left.\times \int_{A_{i^{\prime}}{ }^{\prime}} \sigma d A^{\prime}\right)_{m}+\sum_{j}\left(s_{j}{ }^{\prime} \times \int_{A_{j^{\prime}}} \sigma d A^{\prime}+q_{j}{ }^{\prime}\right. \\
& \left.\times \int_{A_{j^{\prime}}{ }^{\prime}} \sigma d A^{\prime}+t_{j}{ }^{\prime} \times \int_{A_{j^{\prime}}} \sigma_{1} d A^{\prime}\right)_{m}+\sum_{r}\left(s_{r}\right. \\
& \left.\times \int_{A_{r}} \sigma_{2} d A+q_{r} \times \int_{A_{r}} \sigma_{1} d A+t_{r} \times \int_{A_{r}} \sigma_{2} d A\right)_{m} \\
& +\left\{s_{0} \times \int_{A_{0}}\left(\sigma_{2}\right)_{D=0} d A+q_{0} \times \int_{A_{0}}\left(\sigma_{1}\right)_{D=0} d A\right\}_{m} \\
& =0, \text { または } c_{m}
\end{aligned}
$$

次に, 変位成分に対する境界条件の例として, 底面上 の選点 $n$ が変位拘束の条件を持つものとすれば, $x, y$, 
$z$ 各方向の変位成分 $\delta_{n}:(u, v, w)_{n}$ に対して,

$$
\begin{aligned}
\delta_{n} & =\sum_{\boldsymbol{i}}\left(s_{i}{ }^{\prime} \times \int_{A_{i^{\prime}}{ }^{\prime}} \delta d A+q_{i}{ }^{\prime} \times \int_{A_{i^{\prime}}{ }^{\prime}} \delta_{2} d A+t_{i^{\prime}}\right. \\
& \left.\times \int_{A_{i^{\prime}}{ }^{\prime}} \delta A\right)_{n}+\sum_{j}\left(s_{j^{\prime}} \times \int_{A_{j^{\prime}}} \delta_{2} d A+q_{j^{\prime}}\right. \\
& \left.\times \int_{A_{j^{\prime}}} \delta_{2} d A+t_{j}{ }^{\prime} \times \int_{A_{j^{\prime}}} \delta_{1} d A\right)_{n}+\sum_{r}\left(s_{r}\right. \\
& \left.\times \int_{A_{r}} \delta_{2} d A+q_{r} \times \int_{A_{r}} \delta_{1} d A+t_{r} \times \int_{A_{r}} \delta_{2} d A\right)_{n} \\
& +\left\{s_{0} \times \int_{A_{0}}\left(\delta_{2}\right)_{D=0} d A+q_{0} \times \int_{A_{0}}\left(\delta_{1}\right)_{D=0} d A\right\}_{n}=0
\end{aligned}
$$

さらに，図一4には，境界調整の若干の例が示されて いる。図一4（a）は，後の例題にも含まれるが，孔を切

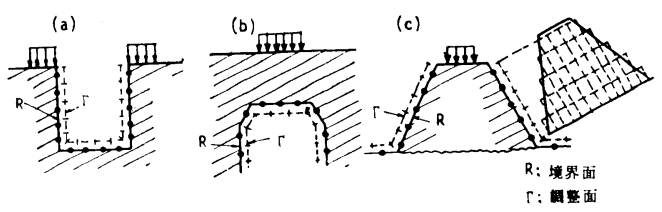

図-4

り取る問題であって，方形ピットの境界面を作るための 調整面の配置を断面図によって表わしたものである。同 様に, 図一4 (b) は, 半無限体内に空洞を作ることによ って, 厚板などの 3 次元解析が可能であることを示して いる。また, 図一4（c）は，斜め長方形有限領域の接合 によって構成される調整面の例を示したものである。

\section{3. 解析例と照査}

ここで注，4つの基礎的な等方性弾性体の問題につい て, 異なった性格を持つ境界調整の精度, 変形, 応力の 分布などについて述べる。そのほか，本解法の連立方程 式に 0 要素を導入して, 計算容量を圧縮する方法を探究 するための，1つの基本的な資料も示される。

まず，図一5，および 表一1 に示すものは，2.(1) で も触れたが，境界調整の精度と，境界面，および調整面 間の距離の関係を示寸一例である。ここでは, 図一5(a) に示ずような, 表面荷重を受ける半無限体内に, 水平,
ならびに垂直な自由面を作る場合について，未調整の状 態で存在した応力（未調整応力）が, 調整によって境界 值（0）に近ゔく模様を示したものである。ところで， 境界面と調整面を一致させれば，応力は，分割されたそ れぞれの有限長方形領域の隅点において発散する。しか し, 両者の距離を, $0.05 a, 0.1 a, 0.15 a$ と変化させた 場合，距離が大きくなるほど，精度が悪化する。もちろ ん，これは一例であって，たとえば，Oliveira ${ }^{12)}$ は，円 孔を持つシャイべの例題において，両者をかなり離した 方がよい結果が得られることを示している。すなわち， この種の精度の検討は, 問題の性格に応じて行なわれる ベきものである。

以下の 4 つの例題における, 調整面の配置, およびそ の分割は，それぞれ若干の検討の後に定められたもので ある。

（1）上面に部分荷重を受ける立方体の問題，ただし 側面は自由, 底面の変位が完全に拘束された場合

図一6 (a) に，問題（1）の立方体（ポアッソン比 v $=0.2$ ） と荷重，および決定された調整面の配置と分割

\begin{tabular}{|c|c|c|c|c|c|c|c|c|}
\hline \multicolumn{2}{|r|}{ 水 } & \multicolumn{2}{|c|}{ 面 } & \multirow{2}{*}{\multicolumn{2}{|c|}{ 心力成分 }} & 直 & 面 & \multirow[b]{2}{*}{$z=0.6 a$} \\
\hline 応力成分 & & $x=0$ & $x=0.2 a$ & & & $z=0.2 a$ & $z=0.4 a$ & \\
\hline$\sigma_{z}$ & $\begin{array}{c}\text { 末調整応力 } \\
e=0.15 a \\
e=0.1 a \\
e=0.05 a\end{array}$ & $\begin{array}{l}-0.335 \\
-0.262 \\
-0.113 \\
-0.0371\end{array}$ & $\begin{array}{r}-0.320 \\
0.0561 \\
0.0337 \\
0.0210\end{array}$ & $\sigma_{x}$ & $\begin{array}{c}\text { 米調整応力 } \\
e=0.15 a \\
e=0.1 a \\
e=0.05 a\end{array}$ & $\begin{array}{c}-0.247 \\
0.104 \\
0.125 \\
0.0590\end{array}$ & $\begin{array}{l}-0.0840 \\
-0.0820 \\
-0.0192 \\
-0.0050\end{array}$ & $\begin{array}{r}-0.0265 \\
0.0692 \\
0.0349 \\
0.0007\end{array}$ \\
\hline
\end{tabular}

(a)

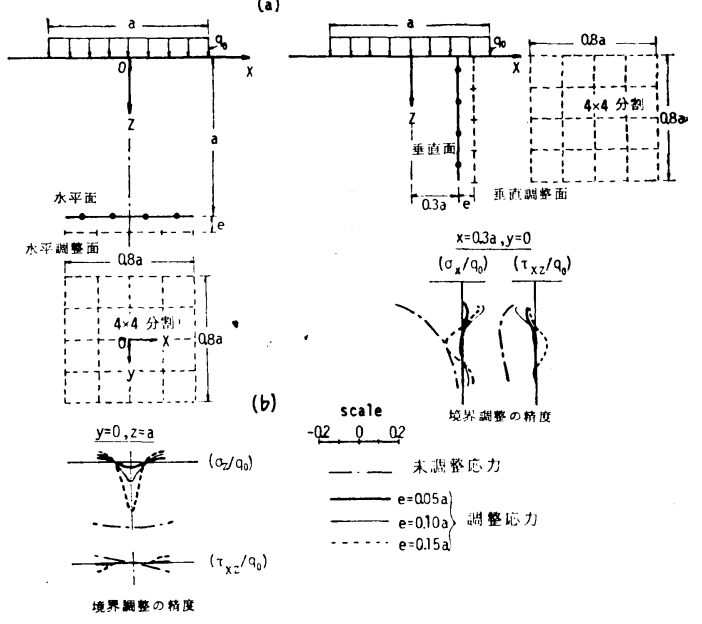

図一5

表一1 調整面の距離（e）と境界調整糖度の関係 
を，また 図一6（b）に境界面上の選点の配置を示す。

図一7 は, 側面における応力, 底面における变位の境 界条件の精度を示すもので, 未調整時の応力, および変 位（半無限体に荷重のみが作用する場合の値：特解の 值）が，調整により，十分な精度で消去されていること がわかる。誤差は, 次の図一8 との対比によってもわか るように，実用上無視できる。なお，図一8 は，応力， ならびに変位の分布を各断面について与えたものであ る。なお, この場合, 調整後のせん断応力の值は, 特異 点（荷重の周辺の近傍）を除くと，一般に小さい值にな るので，データを省略した。また，図一12 には,底面の 垂直応力の分布について, 次の問題 (2)のそれとの比較 がなされている。
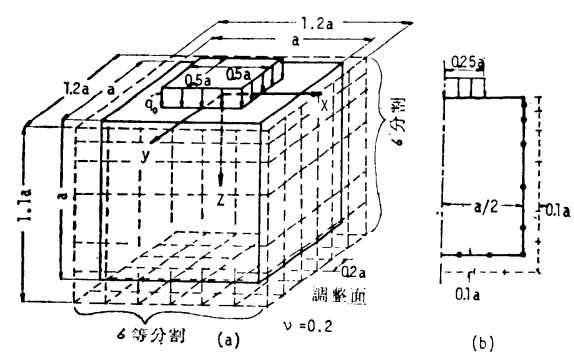

(b)

図-6 問題（1）の立方体と荷重, 調整面の配罝と 分割およひ選点の眍覀

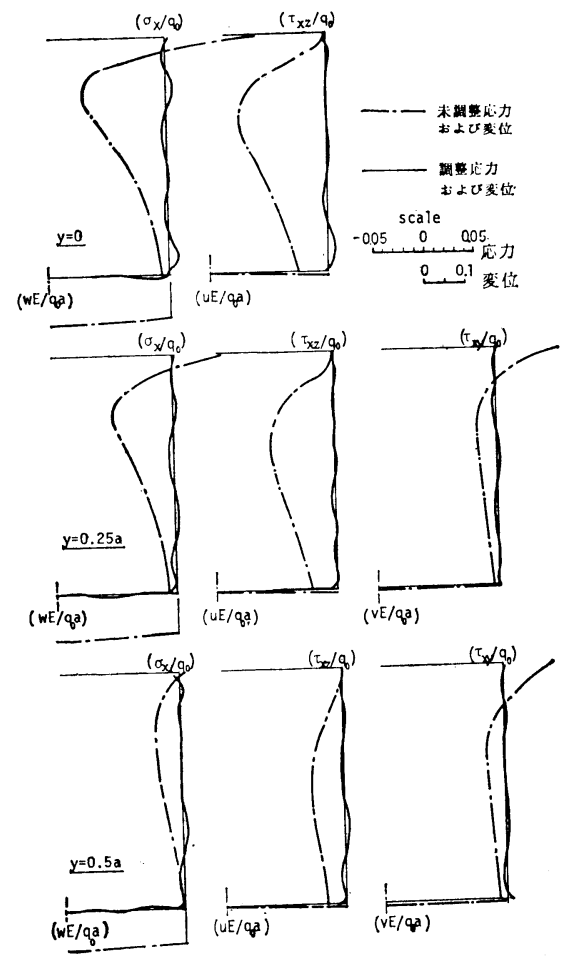

図一7問題 (1) の境界調整の棉度
（2）上面に部分荷重を受ける立方体，ただし，側面 は自由, 底面は半無限体之連続する場合

図一9（a）は，問題（2）の立方体と荷重，および決定 された調整面の配置と分割を，また，図一9（b) は対応 する選点の位置を与えたものである。図一10 は,前題と 同様に，境界条件（すべて応力の条件である）の精度を 示したもので, この場合も，誤差は実用上無視できる。 底面の周辺付近では，応力集中の傾向を持った小さな乱 れが見られるが，周辺上の応力集中の問題は，この付近 の形状をより詳細に与えることによって, 局所的な問題 としてクローズアップし，別個に処理されるべきもので ある。本解析においては, この部分の詳細な検討は行な
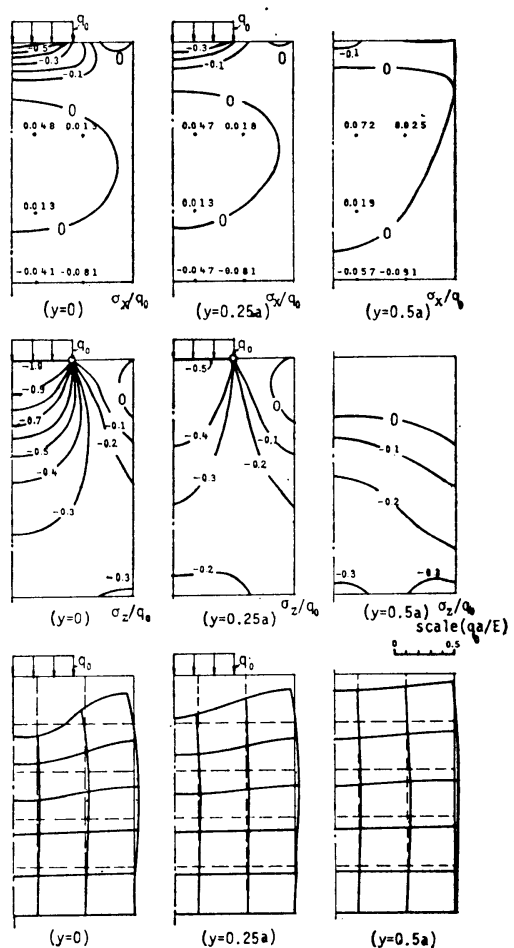

図-8 問題 (1) の立方体の応力, ならびに変位の分布

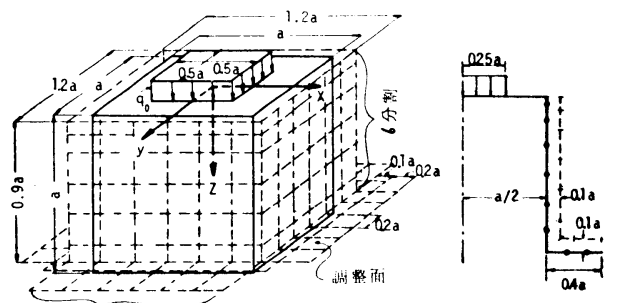

(b)

図一9 問题（2）の立方体と荷重, 調整面の目民国と 分割および選点の眍唒 


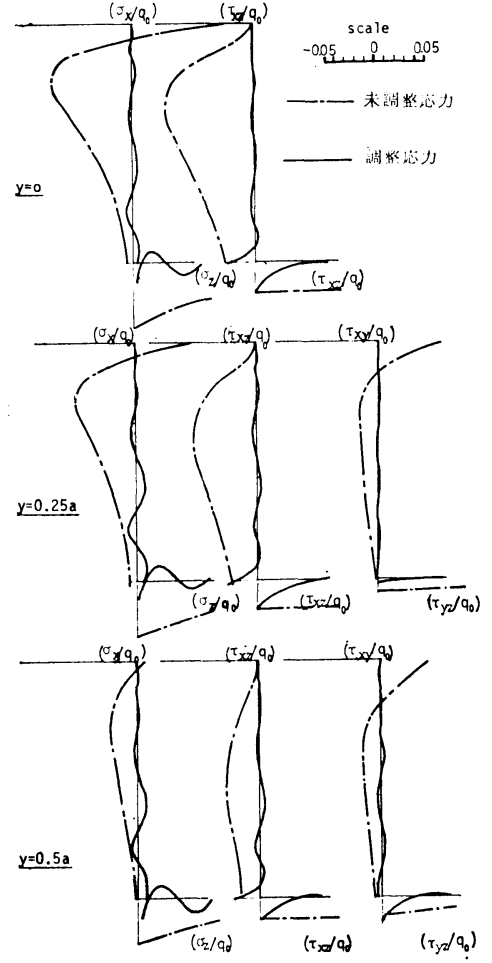

図-10 問題 (2) の境界調整の精度
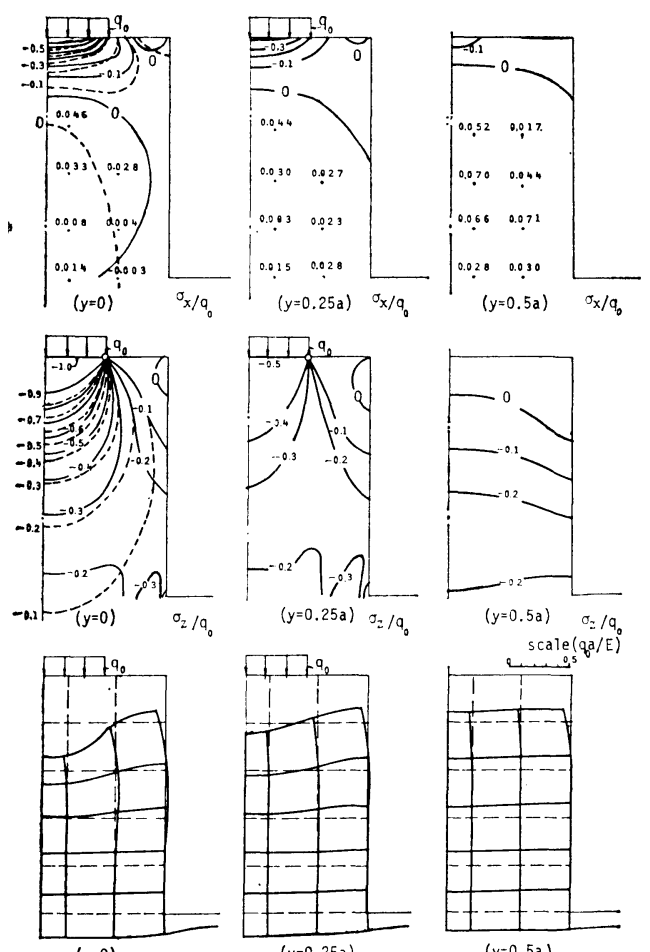

$(y=0.5 a)$

っていない。ただ，たとえば 図一12 の底面内応力の分 布に見るように，応力集中の性状は，周辺よりいくぶん 離れた点において巨視的に捕えられている。

図一11 は，各断面における,応力，ならびに変位の分 布を示したものであり, 特に $y=0$ 断面の忘力分布図で は，未調整時の応力分布（破線）が，調整にともなう側

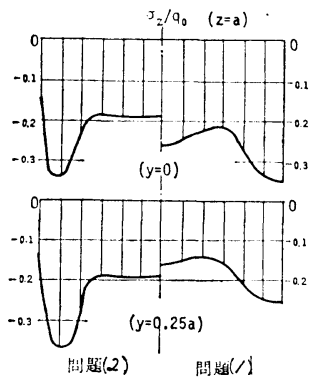

図一12 問題（1），および（2） における底面の直応力分布 面の応力開放によって変 化する模様がよくわか る。

なお，図一12 は,問題 (1)，および（2）におけ る底面の直応力の分布図 である。双方の分布には かなりの差異が見受けら れるが,周辺の近傍では， いずれも応力集中の傾向 を現わしている。

（3）方形孔を持ち，その周囲に表面荷重を受ける半 無限弾性体

この問題は, 前題 (1), (2) とは逆に, 孔を切り取る 問題である。

図一13 に, 方形孔と荷重分布の形, 調整面の配置と分

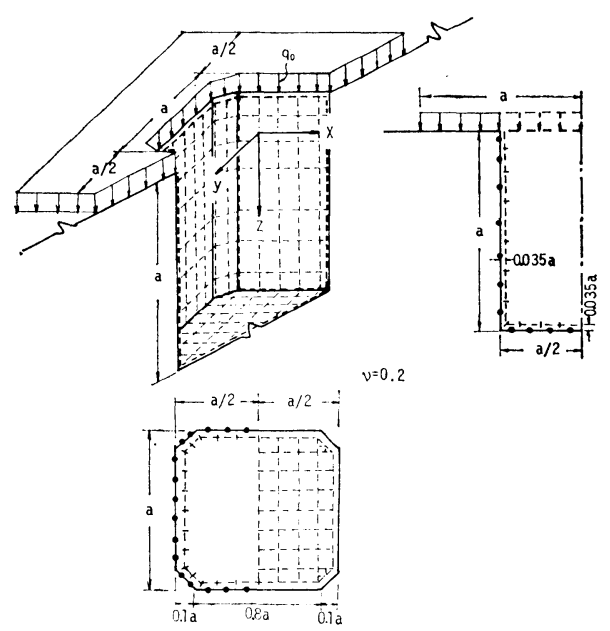

図一13 問題（3）の方形孔と荷重, 調整面の 配置と分割，および選点の配置

割，ならびに選点の配置を示す。すなわち，この場合， 孔の部分も含めて表面荷重を載せた半無限体から，孔の 部分に相当する隅切りを持つ立方体が，その表面荷重と ともに切り取られる。なお， $\nu=0.2$ である。

図一14 は, 境界面の調整の模様を示したもので, 側面

図一11 問題（2）の立方体の応力ならびに 変位の分布

の上下端の付近に若干の誤差を残しているが，それらの 解におよぼす影響は小さいと判断された。また，本例で 

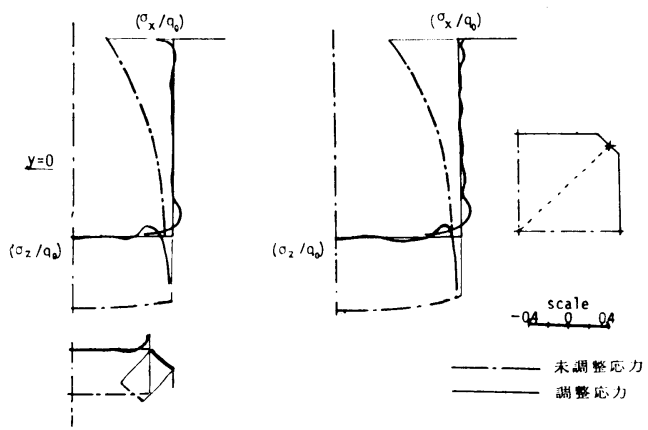

図一14 問題 ( 3 ）の境界調整の精度
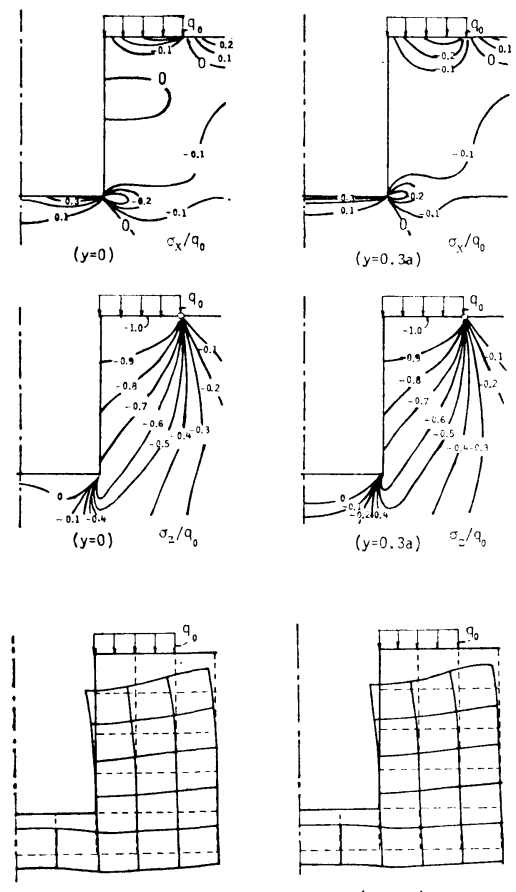

$(y=0.3 a)$
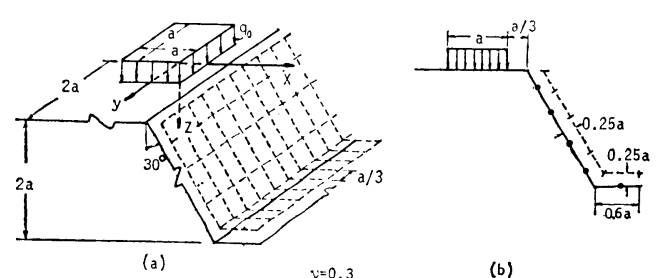

(b)

\section{図一16 斜面と荷重, 調整面の配置と分割および 選点の配蜀}
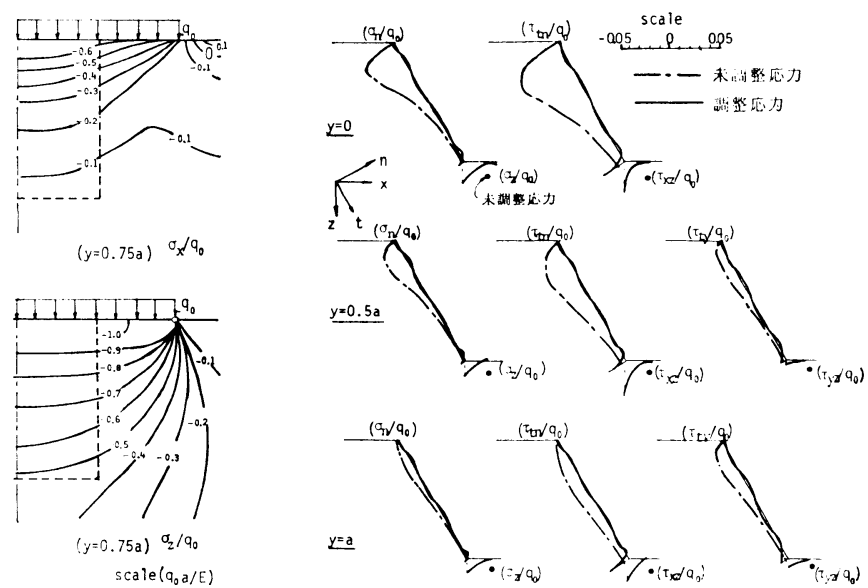

図一17境界調整の精度

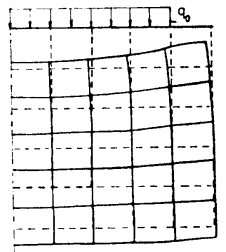

$(y=0.75 a)$

図-15 問題 ( 3 ) の方形孔付近の応力ならびに変位の分布 は，せん断力の調整量流小さく，誤差も問題にならない ので, データを省略した。なお，本解析においても，前 題同様，応力集中に関する局所的な議論はなされていな い。図一15 は, 孔縁付近の応力,ならびに変位の分布を 与えたものである。

\section{（4）上面に部分荷重を受ける，斜面を持つ半無限体} の問題

ここでは，荷重が，斜面の上端からいくぶん離れて作 用する場合と, それに接して作用する場合の 2 つの例が 示される。

図一16(a) は, 前の場合の半無限体と荷重, および調 整面の配置と分割を, また, 図一16(b) に選点の配置を 示す。なお, 境界面の調整は, 後の応力分布図からわか るように, 荷重の影響が十分消滅する位置まで行なわれ
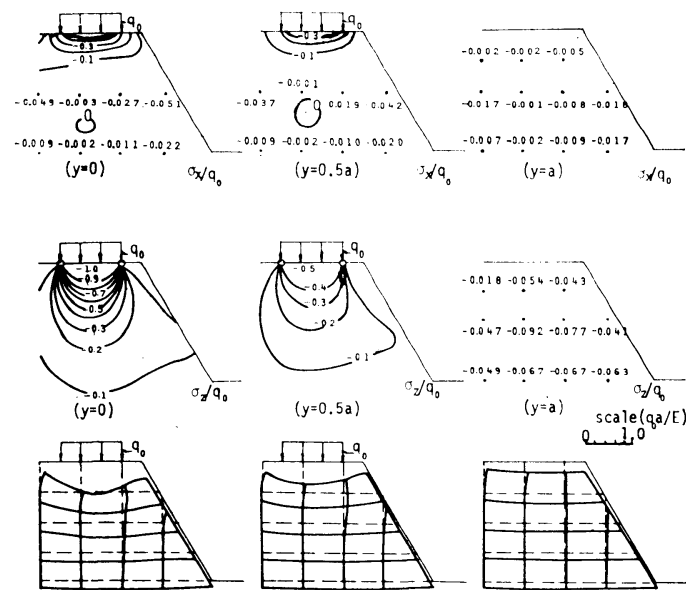

$(y=0)$
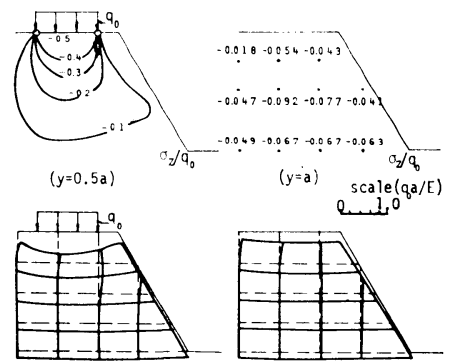

$(y=0.5 a)$

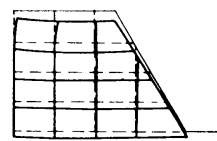

$(y=a)$

图一18 応力ならびに変位の分布 


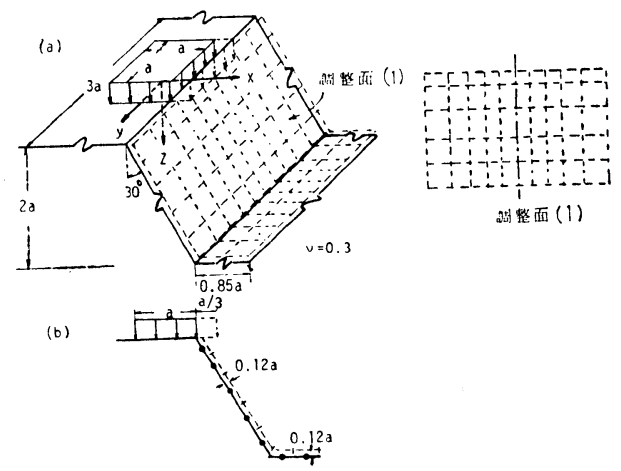

図一19 斜面と荷重，調整面の配圈と分割 および選点の眍置
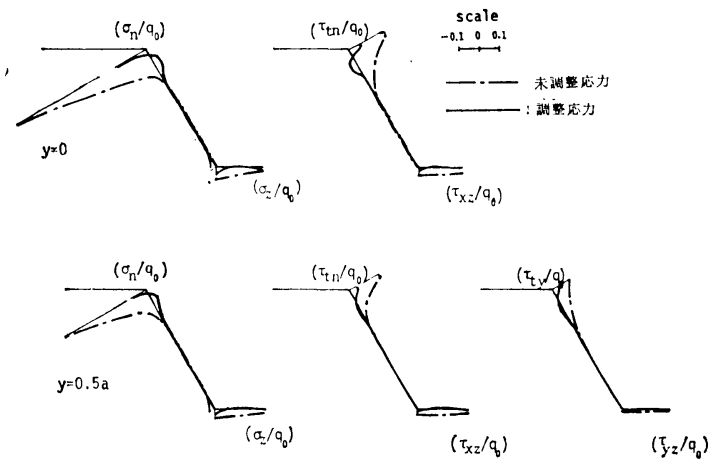

図一20焼界調整の精度

重，調整面の配置と分割，および選点の配置を示す。ま た，図一20 は,境界調整の模様を示したものである。荷 重端，および斜面の下端に特異性に基づく応力集中の傾 向が見られるが，斜面の上端付近では，調整面の分割を 特に細かくしなくても，実用上は十分な結果を得てい る。図一21 は，各断面における応力,および変位の分布 を与えたものである。
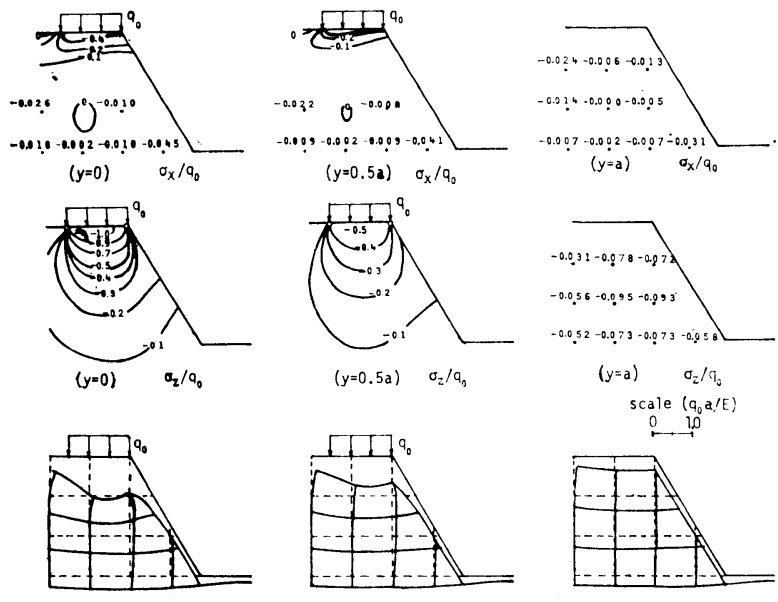

$(y=0)$

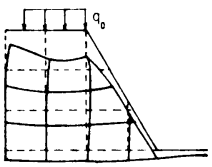

$(y=0.5 a)$
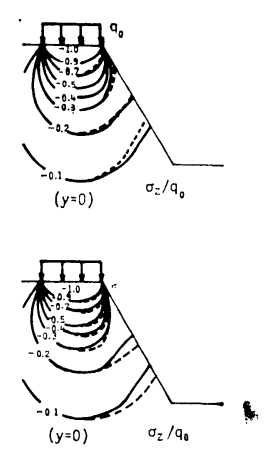

図-23

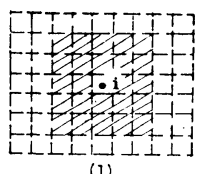

(1)
1.で述べたように，本解法は， いわゆる Integral method に属するもので, 弾性体の 内部には, 解析上の点を配置する必要はなく, 選点の数 は最小限に押えられるが，一方，原則としてマトリック スに 0 要素がない。しかしながら， 3 次元体の内部に与

図一22 影賠範囲の限定
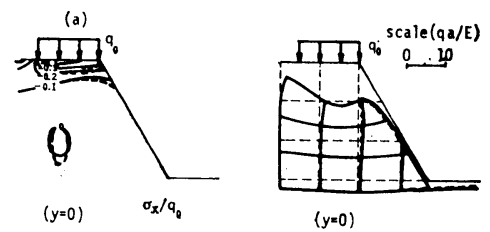

(b)
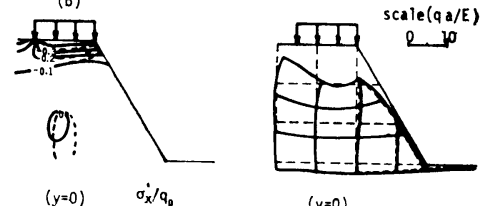

$(y=0)$

調整力の影皚筑囲を限定しない場合

調整力の影翻籍囲を限定する場合

(a)：限定範囲 (1)，(b)：限定籁囲 (2)

えられる 1 つの調整力の影響は，その位置から離れるに 従い，しばしば急激に減少する。この性質を利用して， 1 つの調整力の影響範囲を限定し, それ以外の選点に対 する影響係数を 0 と見なすことにより，マトリックスに 0 要素を導入し, 計算容量を縮小寸る方法が考えられ る。この方法が有効であれば，選点の数を最小限に押え られる解法上の利点と相まって，本解法の有用性をさら に増すことになる。以下，この点に関しての 1 つの 検討例について述べる。

さて，図一19に示した例題が,検討の対象として 選ばれた。この問題では, 斜面の上縁における, 載 荷部分の付近で，特に大きな調整力が与えられてお り，この調整力の影響は，斜面の下方，ならびに側 方におよぶべきものである。いま，ある点 $i$ に作用 する調整力の影響範囲を 図一22 に示すように限定 し, 得られた主要断面の応力, おょび変位の分布 を，影響範囲を限定しない場合の結果（図一21）と 比較したのが 図一23 であるが，影響範囲を限定し ても，実用上は十分な解が得られるようである。こ の事実は,この方法により, 問題によっては SaintVenant の原理を有効に生かして解析を簡易化でき ることを示唆するものである。 


\section{4.あとがき}

いわゆる Integral method を, 3 次元弾性問題に適 用するための 1 つの実用的な手法と, その応用上の問題 点について述へ，4つの基礎的な例題について，異なっ た性格を持つ境界調整の方法, ならびに精度に関するデ 一タを示した。

本文で扱った例題の範囲では, 実用上, 十分な精度を 持つ結果が得られた。このような基本的なデータからも 従来, 2 次元問題に対して, すぐれた成果を提供してい るこの種の方法を, 3 次元問題, 特に, 非軸対称問題の 1 つの有効な解法として拡張できることがうかがわれ, 今後, より広範な問題に対して検討:゙ータを積みあげる 必要性が感じられる。

さらに, 本文に示した 1 つの方法により, 調整力の影 響範囲を制限しても，問題によっては, Saint-Venant の原理が実用的な効果を現わすことが認められた。この 事実は, 解法上, 連立方程式に 0 要素を導入し, 計算容 量を圧縮し得ることを示唆するものであり, 選点の数を 最小限に押えられる解法上の利点と相まって, 本解法の 有用性をさらに增す結果となろら。

\section{参 考 文 献}

1) 岡村宏一: 3 次元弾性非軸問題の 1 解法, 昭和 46 年度土 木学会関西支部講演概要, pp. 1-56-1 4, 1971.

2) 岡村宏一: 3 次元弾性非軸対称問題の解法, 第 26 回土木 学会年次講演会講演概要, $1,1971$.

3) 宮本 博: 3 次元弹性論, 裳華房, 1967.

4) Iyengar, K.T., Sundara Raja and M.K. Prabhakara : A three dimensional elasticity solution for rectangular prism under end loads, Z.A.M.M., Band 49, Heft 6 , pp. 321 332, 1969.

5) Iyengar, K.T., Sundara Raja and M.K. Prabhakara : Anchor zone stresses in prestressed concrete beams, Proc. A.S.C.E., Vol. 97, ST 3, pp. 807 824, 1971.

6) 色部 誠・後藤浩一： 3 次元弹性問題の数値解法, 土 木学会論文集, No. 138, pp. 11 20, 1967.

7) Fjeld, S.A. : Three dimensional theory of elastisity, Finite Element Method in Stress Analysis, Tapir, pp. 333 363, 1969.

8) Argyris, J.H. : Continua and discontinua, Proc. on Matrix Method in Structural Mechanics, WrightPatterson Air Force Base, Ohio, 1965.

9) Melosh, R.J. : Structural analysis of solids, Proc. A.S.C.E., Vol. 89, ST 4, pp. 205 224, 1963.

10) Yettram, A.L. and K. Robbins : Anchorage zone stresses in axially posttensioned members of uniform rectangular section, Magazine of Concrete Research, Vol. 21, No. 67, pp. 103 112, 1969.

11）たとえば,

Rizzo, F.J. : An integral equation approach to boundary value problems of classical elastostatics, Quart. Appl. Math. Vol. 25, No. 1, pp 83 95, 1967.

12) Oliveira, E.R.A., Plane stress analysis by a general integral method, Proc. A.S.C.E., Vol. 94, EM 1, pp. 79 101, 1968.
13）丹羽義次 -小林昭一 - 横田和男 : 空洞周辺忍力の積分方 程式による解析, 昭和 46 年度土木学会関西支部講演概要, pp. $1-54-1 \sim 2,1971$.

14）岡村宏一：構造物の立体解析法，構造物設計法の最近の 進歩と問題点，土木学会関西支部講習会テキスト， pp. 85 86, 1971.

15）岡村宏一・島田 功: 連続斜め P C 板の解析, 昭和 46 年 度土木学会関西支部講演概要, pp. 1-35-1 4, 1971.

16) Mindlin, R.D. : Force at a point in the interior of a semiinfinite solid, Physics, Vol. 7, No. 5, pp. 195 $202,1936$.

\section{付 録}

2.(1) の所論の参考データを付録として示す。

いま, 図一24(a) に示すような, 半無限弾性体内に設 けられた正方形水平面に等分布して作用する鉛直，およ
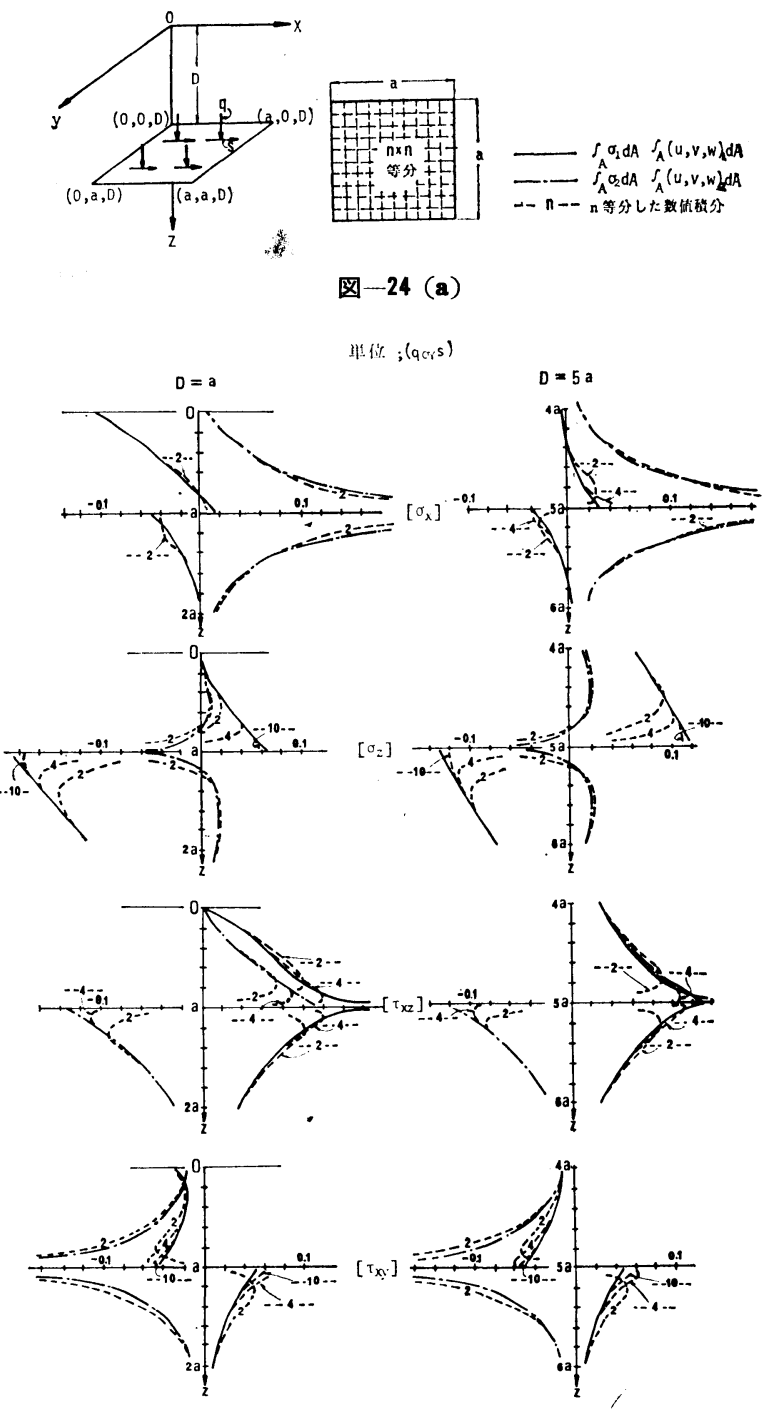

図-24(b) 


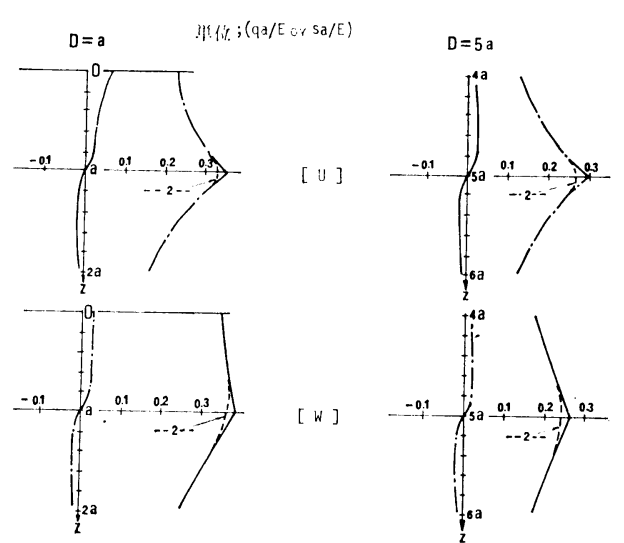

図-24(c)

び水平力による $Z$ 軸上の応力，ならびに変位成分の分布 について，それぞれ，図一24(b)，(c)に，Mindlin解の 積分によって求めた結果と,水平面を $n \times n(n=2,4,10)$ 等分割した集中力の和として，数值積分により求めた結 果との比較を示した。

次に，本解法の基本解として用いる Mindlin 解の重 積分は，すべて積分可能であるが，紙面の都合上，例と して, 図一24 の数值を与える, 応力,および変位の関数 を提示しておく。

ここで,

$$
\begin{aligned}
& \sigma_{x}=\alpha \bar{\sigma}_{x}, \sigma_{y}=\alpha \bar{\sigma}_{y}, \sigma_{z}=\alpha \bar{\sigma}_{z}, \tau_{x y}=\alpha \bar{\tau}_{x y}, \\
& \tau_{x z}=\alpha \bar{\tau}_{x z}, \tau_{y z}=\alpha \bar{\tau}_{y z}, u=\beta \bar{u}, v=\beta \bar{v}, \\
& w=\beta \bar{w},
\end{aligned}
$$

ただし，

$$
\alpha=\frac{1}{8(1-\nu) \pi}, \beta=\frac{1}{16 \pi(1-\nu) G}
$$

$\nu$ : ポアッソン比, $G$ : せん断弾性係数とすると

（1）図一25にみるような Mindlin 第 1 問題の水平 長方形面への積分

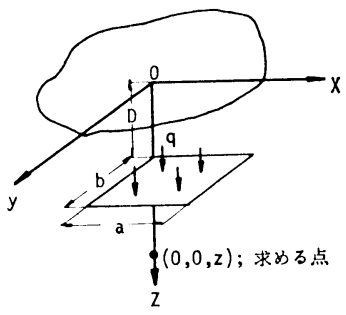

図-25

$$
\begin{aligned}
\overline{\boldsymbol{\sigma}}_{x}= & -2 \nu I_{F_{1}}-2\left(1-2 \nu^{2}\right) I_{F_{2}}+2(1-\nu)(1-2 \nu) I_{F_{5}} \\
& +a \cdot b\left[\frac{z-D}{{C_{1} A_{1}{ }^{2}}}+\frac{1}{C_{2} A_{2}{ }^{2}}\left\{3(z+D)-4 \nu z-\frac{6 D^{2}}{z+D}\right.\right. \\
& \left.\left.-\frac{2\left(a^{2}+b^{2}\right) z D}{C_{2}{ }^{2}(z+D)}-\frac{4 a^{2} z D}{(z+D)^{3}}\left(1-\frac{a^{2}}{{A_{2}}^{2}}\right)-\frac{4 \nu A_{2}{ }^{2} D}{B_{2}{ }^{2}}\right\}\right]
\end{aligned}
$$

$$
\begin{aligned}
\bar{\sigma}_{z}= & -2(1-\nu)\left\{I_{F_{1}}+I_{F_{2}}\right\}-\frac{a b(z-D)}{C_{1}} \times(4) \\
& -\frac{a b D z}{C_{2}(z+D)}\left[\left\{\frac{a^{2}+b^{2}}{3 C_{2}{ }^{2}}+(3-4 \nu) \frac{z}{D}+2(5-2 \nu)\right.\right. \\
& \left.\left.+\frac{D}{z}\right\} \times(5)-4 \times(6)\right] \\
\bar{\tau}_{x y}= & 4(1-\nu)(1-2 \nu) I_{G_{3}}-\left\{\begin{array}{c}
4(1-\nu) \\
* 2(1-2 \nu)
\end{array}\right\}-(z-D) \times(1) \\
& -(3-4 \nu)(z-D) \times(2)-2 D z(z+D) \times(3) \\
& +\frac{D}{z+D}\left(5-8 \nu-\frac{z-D}{z+D}\right) \\
\bar{\tau}_{x z}= & -(1-2 \nu)\left\{I_{G_{1}}-I_{G_{2}}\right\}+b\{(3-4 \nu) z+D\}(z+D) \\
& \times(7)+b\left\{\frac{1}{B_{1}}-\frac{(z-D)^{2}}{A_{1}{ }^{2} C_{1}}\right\}+2 b D z\left[\frac{1}{B_{2}{ }^{3}}\right. \\
& \left.+\frac{1}{A_{2}{ }^{2} C_{2}}\left\{\frac{2 a^{2}}{A_{2}{ }^{2}}-\frac{(z+D)^{2}}{C_{2}{ }^{2}}\right\}\right]
\end{aligned}
$$$$
\left(\bar{\sigma}_{y}, \bar{\tau}_{y z} \text { は，それぞれ } \bar{\sigma}_{x}, \bar{\tau}_{x z} \text { の } x, y\right. \text { 方向の值 }
$$

を入れかえる).

$$
\begin{aligned}
\bar{u} & =(z-D) I_{G f}+\{(3-4 \nu)(z-D) \\
& +4(1-\nu)(1-2 \nu)(z+D)\} I_{G g}+4(1-\nu)(1-2 \nu)\left\{b I_{G h}\right. \\
& \left.+a I_{F g}\right\}+2 b D z(z+D)\left\{\frac{1}{C_{2} A_{2}{ }^{2}}-\frac{1}{B_{2}(z+D)^{2}}\right\} \\
\bar{w} & =(3-4 \nu)\left\{b I_{G a}+a I_{G c}\right\}+\left(5-12 \nu+8 \nu^{2}\right)\left\{b I_{G b}\right. \\
& \left.+a I_{G d}\right\}+\frac{|z-D|}{2}\left\{(5-8 \nu) I_{F a}+I_{F c}+2(3-4 \nu) I_{F e}\right\} \\
& +\frac{z+D}{2}\left\{\left(7-20 \nu+16 \nu^{2}\right) I_{F b}+(3-4 \nu) I_{F d}\right. \\
& \left.+2\left(5-12 \nu+8 \nu^{2}\right) I_{F b}\right\}+\frac{2 a b D Z\left(A_{2}{ }^{2}+B_{2}{ }^{2}\right)}{A_{2}{ }^{2} B_{2}{ }^{2} C_{2}}
\end{aligned}
$$

( $\bar{v}$ は $\bar{u}$ の $x, y$ 方向の值を入れかえる).

（2）図一26にみるような Mindlin 第 2 問題の水平 長方形面への積分

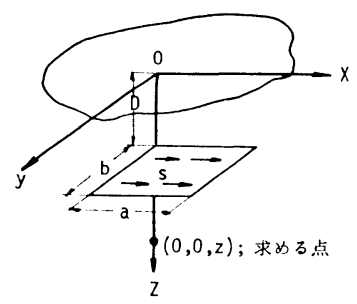

図 -26

$$
\begin{aligned}
\bar{\sigma}_{x}= & -(3-2 \nu) I_{G_{1}}-(5-6 \nu) I_{G_{2}}+2 b D\{z-2 \nu(z+D)\} \\
& \times(7)+4(1-\nu)(1-2 \nu) b \times(8)-a^{2} b\left\{\frac{1}{C_{1} A_{1}{ }^{2}}\right. \\
& \left.+(3-4 \nu) \frac{1}{C_{2} A_{2}^{2}}-\frac{2 D z}{C_{2} A_{2}{ }^{2}}\left(\frac{2}{A_{2}{ }^{2}}+\frac{1}{C_{2}^{2}}\right)\right\} \\
\bar{\sigma}_{y}= & -2 \nu\left\{I_{G_{1}}+(3-4 \nu) I_{G_{2}}\right\}-4 \nu b D(z+D) \times(7) \\
& -4(1-\nu)(1-2 \nu) b \times 8+b\left\{\left(\left(1+\frac{1}{A_{1}}\right)\right.\right.
\end{aligned}
$$




$$
\begin{aligned}
& \left.+(3-4 \nu)\left(2+\frac{1}{A_{2}}\right)-2 D z\left((3)+\frac{1}{A_{2}{ }^{3}}\right)\right\} \\
& \overline{\boldsymbol{\sigma}}_{z}=(1-2 \nu)\left\{I_{G_{1}}-I_{G_{2}}\right\}+b\left\{\left(3 z^{2}-D^{2}\right)-4 \nu z(z+D)\right\} \\
& \times(7)-b\left[\frac{(z-D)^{2}}{C_{1} A_{1}{ }^{2}}-\frac{1}{B_{1}}+2 D z\left\{\frac{2 a^{2}}{C_{2} A_{2}{ }^{4}}-\frac{(z+D)^{2}}{C_{2}{ }^{3} A_{2}{ }^{2}}\right.\right. \\
& \left.\left.+\frac{1}{B_{2}{ }^{3}}\right\}\right] \\
& \bar{\tau}_{x y}=(1-\nu) I_{G_{4}}-a\{4(1-\nu)(1-2 \nu) \times(9)-\text { (1) } \\
& \left.\left.+\frac{1}{B_{1}}\right)-(3-4 \nu)\left((2)+\frac{1}{B_{2}}\right)+2 D z\left((3)+\frac{1}{B_{2}^{3}}\right)\right\} \\
& \overline{\boldsymbol{\tau}}_{x z}=-(1-\nu)\left\{I_{F_{3}}+I_{F_{4}}\right\}+a b\left[\frac{z-D}{\bar{A}_{1}{ }^{2} C_{1}}\right. \\
& \left.+\frac{D z(z+D)}{C_{2} A_{2}{ }^{2}}\left\{\frac{3-4 \nu}{D z}-\frac{2(1-2 \nu)}{z(z+D)}-\frac{6}{A_{2}{ }^{2}}+\frac{2 b^{2}}{{C_{2}}^{2} A_{2}{ }^{2}}\right\}\right] \\
& \bar{\tau}_{y z}=-(z-D)\left\{(1)+\frac{1}{|z-D|}\right\}+\{2(1-2 \nu) z+z \\
& +D\}\left\{(2)+\frac{1}{z+D}\right\}+2 D z(z-D)\left\{(3)+\frac{1}{(z+D)^{3}}\right\} \\
& \bar{u}=4(1-\nu) b\left\{I_{G a}+I_{G b}\right\}+(3-4 \nu) a I_{G c} \\
& +\left(5-12 \nu+8 \nu^{2}\right) a I_{G d}+4(1-\nu)|z-D|\left\{I_{F a}+I_{F e}\right\} \\
& +4(1-\nu)(Z+D)\left\{I_{F b}+I_{F f}\right\} \\
& -4(1-\nu)(1-2 \nu)(z+D) I_{F g}+\frac{2 a b D z}{C_{2} A_{2}{ }^{2}} \\
& \bar{v}=-4(1-\nu)(1-2 \nu)(z+D) I_{G e}-C_{1}+A_{1}+B_{1} \\
& -|z-D|+\left(1-8 \nu+8 \nu^{2}\right)\left(C_{2}-A_{2}-B_{2}+z+D\right) \\
& -2 D z\left(\frac{1}{C_{2}}-\frac{1}{A_{2}}-\frac{1}{B_{2}}+\frac{1}{z+D}\right) \\
& \bar{w}=(z-D) I_{G f}+\{(3-4 \nu)(z-D)-4(1-\nu)(1 \\
& -2 \nu)(z+D)\} I_{G g}-4(1-\nu)(1-2 \nu)\left\{b I_{G h}+a I_{F_{g}}\right\} \\
& -2 b D z(z+D)\left\{\frac{1}{C_{2} A_{2}{ }^{2}}-\frac{1}{B_{2}(z+D)^{2}}\right\}
\end{aligned}
$$

ただし

$$
\begin{aligned}
& A_{1}=\sqrt{a^{2}+(z-D)^{2}} \quad A_{2}=\sqrt{a^{2}+(z+D)^{2}} \\
& B_{1}=\sqrt{b^{2}+(z-D)^{2}} \quad B_{2}=\sqrt{b^{2}+(z+D)^{2}} \\
& C_{1}=\sqrt{a^{2}+b^{2}+(z-D)^{2}} \quad C_{2}=\sqrt{a^{2}+b^{2}+(z+D)^{2}} \\
& I_{F_{1}}=* \pm \sin ^{-1} \frac{a b}{A_{1} B_{1}} \quad I_{F_{2}}=\sin ^{-1} \frac{a b}{A_{2} B_{2}} \\
& I_{F_{3}}=* \pm\left\{\sin ^{-1} \frac{A_{1}^{2}+a C_{1}}{A_{1}\left(C_{1}+a\right)}-\sin ^{-1} \frac{A_{1}^{2}-a C_{1}}{A_{1}\left(C_{1}-a\right)}\right\} \\
& I_{F_{4}}=\sin ^{-1} \frac{A_{2}{ }^{2}+a C_{2}}{A_{2}\left(C_{2}+a\right)}-\sin ^{-1} \frac{A_{2}{ }^{2}-a C_{2}}{A_{2}\left(C_{2}-a\right)}
\end{aligned}
$$

$$
\begin{aligned}
& I_{F_{5}}=\sin ^{-1} \frac{a b\left(a^{2}+b^{2}\right)}{A_{2} B_{2}\left\{C_{2}^{2}+\left(2 C_{2}+z+D\right)(Z+D)\right\}} \\
& I_{G 1}=\log \frac{|z-D|\left(C_{1}+b\right)}{A_{1}\left(B_{1}+b\right)} \quad I_{G_{2}}=\log \frac{(z+D)\left(C_{2}+b\right)}{A_{2}\left(B_{2}+b\right)} \\
& I_{G 3}=\log \frac{\left(A_{2}+z+D\right)\left(B_{2}+z+D\right)}{2(z+D)\left(C_{2}+z+D\right)} \\
& I_{G 4}=\log \frac{\left(A_{1}+a\right)\left(A_{2}+a\right)\left(C_{1}-a\right)\left(C_{2}-a\right)}{\left(A_{1}-a\right)\left(A_{2}-a\right)\left(C_{1}+a\right)\left(C_{2}+a\right)} \\
& \text { (1) }=\frac{1}{C_{1}}-\frac{1}{B_{1}}-\frac{1}{A_{1}} \quad \text { (2) }=\frac{1}{C_{2}}-\frac{1}{B_{2}}-\frac{1}{A_{2}} \\
& \text { (3) }=\frac{1}{C_{2}{ }^{3}}-\frac{1}{B_{2}{ }^{3}}-\frac{1}{A_{2}{ }^{3}} \quad \text { (4) }=\frac{1}{{A_{1}{ }^{2}}^{2}}+\frac{1}{B_{1}{ }^{2}}
\end{aligned}
$$

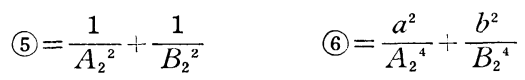

$$
\begin{aligned}
& \text { (7) }=\frac{1}{B_{2}(z+D)^{2}}-\frac{1}{A_{2}^{2} C_{2}} \quad(8)=\frac{1}{C_{2}+z+D}-\frac{1}{B_{2}+z+D} \\
& \text { (9) }=\frac{1}{C_{2}+z+D}-\frac{1}{A_{2}+z+D} \\
& I_{F a}=\sin ^{-1} \frac{b^{2}-C_{1}\left(C_{1}+a\right)}{\left(C_{1}+a\right) A_{1}} \quad I_{F b}=\sin ^{-1} \frac{b^{2}-C_{2}\left(C_{2}+a\right)}{\left(C_{2}+a\right) A_{2}} \\
& I_{F c}=\sin ^{-1} \frac{b^{2}-C_{1}\left(C_{1}-a\right)}{\left(C_{1}-a\right) A_{1}} \quad I_{F d}=\sin ^{-1} \frac{b^{2}-C_{2}\left(C_{2}-a\right)}{\left(C_{2}-a\right) A_{2}} \\
& I_{F e}=\sin ^{-1} \frac{|z-D|}{B_{1}} \quad I_{F f}=\sin ^{-1} \frac{z+D}{B_{2}} \\
& I_{F g}=\sin ^{-1} \frac{b^{2}-C_{2}\left(C_{2}+z+D\right)}{\left(C_{2}+z+D\right) A_{2}}+\frac{\pi}{2} \\
& I_{F h}=\sin ^{-1} \frac{a^{2} b^{2}-C_{2}{ }^{2}(z+D)}{A_{2}{ }^{2} B_{2}{ }^{2}}+\frac{\pi}{2} \\
& I_{G a}=\log \frac{C_{1}+a}{B_{1}} \quad I_{G b}=\log \frac{C_{2}+a}{B_{2}} \quad I_{G c}=\log \frac{C_{1}+b}{A_{1}} \\
& I_{G d}=\log \frac{C_{2}+b}{A_{2}} \quad I_{G e}=\log \frac{2\left(C_{2}+z+D\right)(z+D)}{\left(A_{2}+z+D\right)\left(B_{2}+z+D\right)} \\
& I_{G f}=\log \frac{\left(C_{1}+b\right)|z-D|}{A_{1}\left(B_{1}+b\right)} \quad I_{G g}=\log \frac{\left(C_{2}+b\right)(z+D)}{A_{2}\left(B_{2}+b\right)} \\
& I_{G h}=\log \frac{C_{2}+z+D}{B_{2}+z+D} \\
& \text { * は } D>z \text { の場合 }
\end{aligned}
$$$$
\text { なお, これらの応力, および変位成分は, 長方形面の }
$$
1 つの隅点を通る線上の点に対して与えられるが，重ね 合わせによって，任意の長方形，および任意点に対する 応力が求まる。

(1971.8.18 - 受付) 